\title{
PENGARUH TINGKAT PERPUTARAN PIUTANG DAN TINGKAT PER- PUTARAN PERSEDIAAN TERHADAP RENTABILITAS (Studi Kasus pada PT. ABM Otomotif Batam)
}

\section{THE EFFECT OF RECEIVABLES AND LEVEL OF INVENTORY ROUND ON RENT- ABILITY (Case Study at PT. ABM Otomotif Batam)}

\author{
Dian Nuraeni ${ }^{1}$, Jayana Salesti ${ }^{2}$ \\ ${ }^{1}$ (Akuntansi, Ekonomi, Universitas Riau Kepulauan, Indonesia) \\ ${ }^{2}$ (Akuntansi, Ekonomi, Universitas Riau Kepulauan, Indonesia) \\ 'sjayana97@yahoo.com
}

\begin{abstract}
Abstrak
Tujuan dari penelitian ini adalah untuk mengetahui apakah perputaran piutang dan perputaran persediaan berpengaruh terhadap Rentabilitas pada PT. ABM Otomotif Batam tahun 2014-2016. Metode yang digunakan dalam penelitian ini adalah bersifat kuantitatif.Teknik analisis data yang digunakan dalam penelitian ini adalah analisis regresi linier berganda dengan menggunakan bantuan software SPSS (Statistical Product and Service Solution) versi 20.Hasil penelitian pada uji F menunjukan bahwa perputaran piutang dan perputaran persediaan secara simultan berpengaruh simultan terhadap Rentabilitas ( Return On Asset ). Secara uji t perputaran piutang berpengaruh secara parsial terhadap Rentabilitas ( Return On Asset ), sedangkan perputaran persediaan tidak berpengaruh secara parsial terhadap rentabilitas ( Return On Asset ) pada PT. ABM Otomotif Batam pada tahun 2014-2016.
\end{abstract}

Kata Kunci ; Perputaran Piutang, Perputaran Persediaan, Rentabilitas, Return On Asset

\begin{abstract}
These purpose of this study is to determine whether the turnover of receivables and inventory turnover affect on profitability at PT. ABM Otomotif Batam 2014-2016. The method used in this research is quantitative in which the data can be measured and assessed with the numbers directly. Data analysis technique used in this research is multiple linear regression analysis using SPSS (Statistical Product and Service Solution) version 20 software. These result of the research on $F$ test shows that receivable turnover and inventory turnover simultaneously affect the rentability. In test t receivable turnover partially significant influence on Rentability, while inventory turnover does not partially significant effect on rentability (Return On Asset) at PT. ABM Otomotif Batam in 2014-2016.
\end{abstract}

Keywords ; Receivable Turnover, Inventory Turnover, Rentability, Return On Asset.

\section{PENDAHULUAN}

Secara umum tujuan utama dari suatu perusahaan adalah untuk memperoleh profit atau laba. Laba tersebut diperoleh dari aktivitas atau kinerja perusahaan. Suatu perusahaan dikatakan dalam kondisi baik (dapat bekerja secara efisien) apabila laba yang diperoleh selalu meningkat. Hal tersebut dapat dilihat dari laporan rugi laba yang menunjukkan kinerja perusahaan selama satu periode 
akuntansi. Namun, di dalam kasus ini ukuran keberhasilan suatu perusahaan tidak hanya diukur dari pencapaian labanya saja. Pencapaian laba yang tinggi tidak dapat dijadikan ukuran bahwa perusahaan tersebut telah bekerja secara efisien.

Suatu perusahaan dikatakan dapat bekerja secara efektif dan efisien apabila terjadi perputaran modal kerja yang baik, artinya modal kerja tersebut terus berputar dengan tingkat perputaran yang tinggi, sehingga dengan tingginya tingkat

Rentabilitas perusahaan yang tinggi dapat dipengaruhi oleh beberapa faktor, antara lain, perputaran piutang dan perputaran persediaan. Perputaran piutang yang cepat mencerminkan perusahaan memiliki peforma penjualan kredit yang baik. Dimana semakin besar penjualan kredit diharapkan tingkat rentabilitas perusahaan semakin besar. Penjualan secara kredit dapat digunakan oleh perusahaan sebagai strategi untuk menarik pelanggan baru ataupun mempertahankan pelanggan lama, dikarena sebagian pelanggan lebih memilih membeli barang dengan harga yang sedikit lebih mahal tetapi dapat memperoleh termin kredit yang panjang. Perputaran modal kerja tersebut maka akan semakin tinggi pula pencapaian laba perusahaan dan hal ini sekaligus dapat meningkatkan rentabilitas ekonomi perusahaan.

Piutang dan persediaan adalah elemen dari modal kerja yang sangat penting pengelolaannya untuk mencapai tingkat rentabilitas yang maksimal. Tingkat perputaran piutang dan persediaan yang tinggi menunjukkan bahwa perusahaan dapat memaksimalkan rentabilitasnya. Menurut kasmir ( 2010 : 176 ) perputaran piutang merupakan rasio yang digunakan untuk mengukur berapa lama penagihan piutang selama satu periode atau berapa kali dana yang ditanam dalam piutang ini berputar dalam satu periode. Pendapat lain mengenai perputaran piutang menurut Susan Irawati ( 2006 : 54 ) Receivable Turnover (RT) merupakan rasio yang digunakan untuk mengukur efektifitas pengelolaan piutang.

\section{TINJAUAN PUSTAKA \\ Pengertian Piutang}

Menurut Martono dan Harjito ( 2007:95 ) piutang dagang (account receivable) merupakan "tagihan perusahaan kepada pelanggan atau pembeli atau pihak lain yang membeli produk perusahaan". Smith (2007 : 286) mengatakan "piutang dapat didefinisikan dalam arti luas sebagai hak atau klaim terhadap pihak lain atas uang, barang, dan jasa. Namun, untuk tujuan akuntansi, istilah ini umumnya diterpakan sebagai klaim yang diharapkan dapat diselesaikan melalui penerimaan kas".

Secara umum piutang dapat didefinisikan sebagai tagihan atau aktiva perusahaan yang timbul akibat terjadinya penjualan barang atau jasa secara kredit yang dilakukan oleh suatu perusahaan. Berdasarkan pengertian-pengertian piutang diatas, maka dapat disimpulkan bahwa piutang sangat penting bagi perusahaan karena piutang merupakan salah satu investasi dari aktiva lancar, maka piutang dianggap memiliki waktu perputaran yang cepat dari satu tahun sehingga aktiva ini mudah dicairkan menjadi uang kas.

\section{Perputaran Piutang}

Perputaran piutang ini menunjukkan berapa kali sejumlah modal yang tertanam dalam piutang yang berasal dari penjualan kredit berputar dalam satu periode. Dengan kata lain, rasio perputaran piutang bisa diartikan berapa kali suatu perusahaan dalam setahun mampu mengembalikan atau menerima kembali kas dari piutangnya. 
Menurut Kasmir(2010:247)

bahwa perputaran piutang merupakan rasio yang digunakan untuk mengukur berapa lama penagihan piutang selam satu periode. Atau berapa kali dana yang ditanam dalam piutang ini berputar dalam satu periode. Tingkat perputaran piutang tersebut dapat dihitung dengan:

\section{Receiveable Turnover $=$ Penjualan Kredit Piutang}

\section{Pengertian Persediaan}

Menurut Atmaja (2008:405) Persediaan merupakan salah satu komponen modal kerja yang tingkat likuiditasnya paling rendah dibandingkan dengan komponen modal kerja lainnya. Jumlah dan jenis persediaan sangat tergantung pada besar dan bentuk perusahaan. Dalam beberapa bentuk, persediaan perusahaan dapat mencapai lebih dari lima puluh persen asset perusahaan,sehingga dana yang di investasikan dalam persediaan juga sangat besar.

Manajemen persediaan membutuhkan dibentuknya suatu system pengendalian persediaan. Sistem pengendalian persediaan dapat berbentuk sangat sederhana menjadi luar biasa kompleks, tergantung pada ukuran perusahaan dan sifat persediaannya. Manajemen invento$r y$ (persediaan) adalah kontrol atas segenap aktiva yang merupakan produk perusahaan, yang diperjual belikan dalam operasi sehari hari.

Persediaan yang dimiliki oleh perusahaan terdiri dari beberapa jenis, dan tergantung dari jenis perushaannya. Artinya, jenis persediaan untuk perusahaan manufaktur berbeda dengan perusahaan dagang atau perusahaan jasa. Khusus untuk perusahaan dagang biasanya hanya terdiri dari persediaan barang jadi namun item barangnya relatif banyak dari perusahaan manufaktur. Begitu pula dengan perusahaan jasa, jenis persediaan yang dimiliki relatif lebih sedikit jika dibandingkan dengan perusahaan manufaktur. Sedangkan untuk perusahaan manufactur, mula-mula persediaannya belum siap untuk dijual sehingga perlu diolah terlebih dahulu.

\section{Perputaran Persediaan}

Menurut Kasmir (2008:180) perputaran persediaan merupakan rasio yang digunakan untuk mengukur berapa kali dana yang ditanam dalam sediaan (inventory) ini berputar dalam satu periode. Dapat diartikan pula bahwa perputaran sediaan merupakan rasio yang menunjukkan berapa kali jumlah barang sediaan diganti dalam satu tahun.

Syamsuddin (2011: 47 - 48 ) juga menambahkan untuk menghitung perputaran persediaan dan menghitung umur rata - rata persediaan adalah :

$\begin{aligned} & \text { Inventory Turnover } \\ & \text { Goods Sold }\end{aligned}$
Inventory

\section{Pengertian Rentabilitas}

Menurut Bambang Riyanto (2011:59) bahwa "Rentabilitas adalah suatu perusahaan membandingkan laba dengan aktiva atau modal yang menghasilkan modal tersebut" sedangkan menurut Munawir (2010:33) bahwa "Rentabilitas merupakan kemampuan perusahaan menghasilkan laba pada periode tertentu" menurut Harahap (2010:304) "Rasio Rentabilitas atau biasa disebut juga profitabilitas menggambarkan kemampuan perusahaan mendapatkan laba 
melalui semua kemampuan dan sumber yang ada seperti penjualan, kas, modal, jumlah karyawan, jumlah cabang, dan sebagainya"

Berdasarkan pendapat diatas dapat disimpulkan bahwa profitabilitas atau rentabilitas adalah rasio untuk mengukur efektifitas manajemen berdasarkan hasil pengembalian yang dihasilkan dari volume penjualan total aktivita dan modal sendiri. Maka baik perusahaan maupun koperasi tidak hanya berusaha untuk memperbesar laba, tetapi yang lebih penting ialah usaha untuk mempertinggi rentabilitasnya. Tujuan operasional dari sebagian besar perusahaan adalah untuk memaksimalkanprofit, baik profit jangka pendek maupuin profit jangka panjang. Manajemen dituntun untuk meningkatkan imbal hasil (return) bagi pemilik perusahaan, dan meningkatkan kesejahteraan karyawan. Ini semua hanya dapat terjadi apabila perusahaan memperoleh laba dalam aktivitas bisnisnya.

\section{Kerangka Berfikir}

Untuk mengetahui gambaran mengenai penelitian ini, maka diperlukan sebuah kerangka pemikiran yang sistematis untuk memecahkan masalah. Dalam kerangka pemikiran ini dijelaskan gambaran masalah yang diteliti secara singkat hubungan variable yang diteliti yaitu mengenai pengaruh tingkat perputaran piutang dan tingkat perputaran persediaan terhadap rentabilitas perusahaan. Penelitian dapat digambarkan dengan model penelitian sebagai berikut:

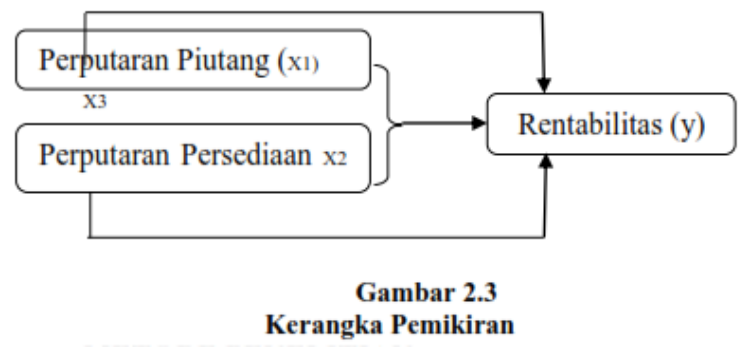

\section{METODE PENELITIAN \\ Objek dan Lokasi Penelitian}

Objek dalam penelitian ini difokuskan pada PT. ABM Otomotif Batam dalam periode laporan keuangan 2013 - 2015 yang berlokasi di Komplek Bumi Riau Makmur Blok F No. 04 Sei Panas - Batam, Kode Pos : 29433, Telepon : (0778) 433233.

\section{Jenis Penelitian}

Jenis penelitian yang dilakukan peneliti adalah bersifat kuantitatif yang mana data tersebut dapat diukur dan dinilai dengan angka-angka secara langsung.

\section{Jenis Data}

Jenis data yang digunakan adalah data sekunder merupakan data yang diperoleh dari sumber yang sudah ada atau data primer yang diperoleh dari sumber yang menerbitkannya kemudian dioleh oleh peneliti, umumnya berupa bukti, catatan atau laporan historis yang telah tersusun dalam arsip (data documenter) yang dipublikasikan.

\section{Definisi Operasional Variabel}

Menurut Sugiyono (2012:58) variabel penelitian adalah segala sesuatu yang berbentuk apa saja yang ditetapkan oleh peneliti untuk dipelajari sehingga diperoleh informasi tentang hal tersebut, kemudian 
ditarik kesimpulannya. Variabel independen dalam penelitian ini adalah perputaran piutang (X1), dan perputaran persediaan (X2), sedangkan variable dependen adalah rentabilitas perusahaan (Y). Masing-masing definisi operasional variabel akan dijelaskan sebagai berikut. Variabel independen dalam penelitian ini adalah :

1. Perputaran Piutang (Receivable Turnover)

Salah satu caa menilai berhasil tidaknya kebijakan penjualan kredit yang dilaksanakan oleh perusahaan dapat dilakukan dengan melihat perputaran piutang. Perputaran Piutang yaitu kemampuan dana yang tertanam dalam piutang berputar dalam satu periode tertentu melalui penjualan. Perputaran piutang dihitung dengan cara membandingkan penjualan dengan rata-rata piutang yang merupakan hasil dari saldo awal piutang ditambah saldo piutang akhir perusahaan dibagi dua.

\section{PerputaranPiutang $=$
Rata - Penjualan Piutang}

2. Perputaran persediaan (Inventory Turnover)

Yaitu kemampuan dana yang tertanam dalam persediaan berputar dalam satu periode tertentu. Perputaran persediaan dihitung dengan cara membandingkan harga pokok penjualan dengan rata-rata persediaan yang merupakan hasil dari saldo ditambah saldo persediaan akhir perusahaan dibagi dua.

\section{Perputaran Persediaan $=\underline{H P P R a t a}-$ Rata Persediaan}

Dengan umur rata-rata persediaan dimaksudkan berapa hari secara rata-rata persediaan berada didalam perusahaan. Variabel Dependen dalam penelitian ini adalah :

1. Rentabilitas (Rentability)

Dalam penelitian ini, peneliti menggunakan Ratio Rentabilitas yaitu Return On Asset (ROA), yang mana Return On Asset adalah kemampuan suatu perusahaan untuk menghasilkan laba yang berkaitan dengan hasil penjualan dan penggunaan sumber-sumber yang ada.

Return On Asset $($ ROA $)$
$\frac{\text { Laba setelah pajak }}{\text { Total Aktiva }}$

\section{Teknik Analisis Data}

Teknik analisis data yang digunakan dalam penelitian ini adalah analisis regresi linier berganda dengan menggunakan bantuan software SPSS (Statistical Product and Service Solution) versi 20.

\section{HASIL PENELITIAN DAN PEMBAHA- SAN}

\section{Gambaran Umum Perusahaan}

Gemar / hobby dalam dunia Otomotif khususnya Offroad, tentu membutuhkan suatu sarana untuk me-modif atau memperbaiki mobil sesuai dengan keinginan kita sendiri. Dan juga kadang kalau kita ingin me-modifikasi mobil kita sendiri ke bengkel Jeep khususnya, tentu banyak kendala dilihat dari segi waktu dan juga kadang apa yang kita inginkan tidak sesuai dengan harapan kita.

Berdasarkan dari itu semua, kami berpendapat bahwa " Daripada ke bengkel orang lain, lebih baik kami membuka bengkel sendiri terutama bengkel khusus perbaikan jeep saja ". Begitulah sejarah singkat yang melatarbelakangi berdirinya 
Bengkel ABM ini. Seiring dengan waktu dan karena didukung oleh dana, masukan / ide dari teman-teman, dan juga dari Pihak Management sendiri, maka muncullah ide untuk memuka bengkel umum dan bukan hanya untuk bengkel Jeep saja. 17 April 2011 secara resmi Bengkel ABM dibuka dan mulai beroperasi serta dilengkapi dengan alat yang begitu canggih seperti Lift, Alat Dongkrak Set, dan Tools Set, Car Wash, Pengecatan Mobil, dan Variasi Mobil sebagai layanan tambahan bagi konsumen kami, termasuk juga alat yang masih langka dulunya di bengkel lain yaitu alat Engine Analyzer Mobil yaitu Lounch dan Car Man dimana kita bisa tahu apa penyakit mobil dengan cara scanning menggunakan alat tersebut.

\section{Pengujian Data dan Hasil Statistik Deskriptif Variabel Penelitian}

Tabel 4.4 Data Penelitian

\begin{tabular}{|c|c|c|c|c|c|}
\hline $\begin{array}{l}\mathbf{N} \\
\mathbf{0}\end{array}$ & Tahun & Bulan & R.T & I.T & $\mathbf{R O A}$ \\
\hline 1 & \multirow{12}{*}{2014} & Jan & 0.1329 & 0.4289 & $(0.0111)$ \\
\hline 2 & & Feb & 0.1283 & 0.2828 & 0.0027 \\
\hline 3 & & Mar & 0.1925 & 0.5083 & 0.0237 \\
\hline 4 & & Apr & 0.1228 & 0.3534 & 0.0043 \\
\hline 5 & & Mei & 0.1477 & 0.3750 & 0.0164 \\
\hline 6 & & Jun & 0.1893 & 0.6624 & 0.0299 \\
\hline 7 & & Jul & 0.1009 & 0.4199 & $(0.0161)$ \\
\hline 8 & & Agus & 0.1484 & 0.2322 & 0.0351 \\
\hline 9 & & Sept & 0.1712 & 0.4293 & 0.0285 \\
\hline 10 & & Okt & 0.0867 & 0.2767 & $0.0016)$ \\
\hline 11 & & Nov & 0.1075 & 0.4241 & $0.0025)$ \\
\hline 12 & & Des & 0.2444 & 0.7910 & 0.0297 \\
\hline 13 & \multirow{12}{*}{2015} & Jan & 0.1915 & 0.7077 & 0.0044 \\
\hline 14 & & Feb & 0.1368 & 0.4024 & 0.0010 \\
\hline 15 & & Mar & 0.1989 & 0.6931 & 0.0091 \\
\hline 16 & & Apr & 0.1432 & 0.5049 & 0.0007 \\
\hline 17 & & Mei & 0.1508 & 0.4909 & 0.0052 \\
\hline 18 & & Jun & 0.4074 & 1.3578 & 0.0276 \\
\hline 19 & & Jul & 0.1871 & 0.9354 & 0.0016 \\
\hline 20 & & Agus & 0.2028 & 1.0530 & 0.0126 \\
\hline 21 & & Sept & 0.1851 & 0.7479 & 0.0081 \\
\hline 22 & & Okt & 0.1216 & 0.4171 & 0.0025 \\
\hline 23 & & Nov & 0.1754 & 0.6517 & 0.0121 \\
\hline 24 & & Des & 0.2399 & 0.9583 & 0.0091 \\
\hline 25 & \multirow{9}{*}{2016} & Jan & 0.2281 & 1.0354 & 0.0029 \\
\hline 26 & & Feb & 0.1748 & 0.6186 & 0.0050 \\
\hline 27 & & Mar & 0.2243 & 0.8067 & 00314 \\
\hline 28 & & Apr & 0.1046 & 0.4336 & $(0.0037)$ \\
\hline 29 & & Mei & 0.2353 & 1.0392 & 0.0119 \\
\hline 30 & & Jun & 0.2556 & 1.3337 & 0.0107 \\
\hline 31 & & Jul & 0.2402 & 1.2544 & 0.0107 \\
\hline 32 & & Agus & 0.1742 & 0.6797 & 0.0103 \\
\hline 33 & & Sept & 0.2541 & 1.3507 & 0.0167 \\
\hline
\end{tabular}

Tabel 4.5 Statistik Deskriptif Descriptive Statistics

\begin{tabular}{|c|c|c|c|c|c|}
\hline & $\mathrm{N}$ & $\begin{array}{c}\text { Minim } \\
\text { um }\end{array}$ & $\begin{array}{c}\text { Maxim } \\
\text { um }\end{array}$ & Mean & $\begin{array}{c}\text { Std. } \\
\text { Deviatio } \\
\mathbf{n}\end{array}$ \\
\hline $\begin{array}{l}\text { Perputaran } \\
\text { _Piutang } \\
\text { Perputaran } \\
\text { _Persediaa } \\
\text { nentabilita } \\
\text { R_ROA } \\
\text { Valid N } \\
\text { (listwise) }\end{array}$ & $\begin{array}{l}36 \\
36 \\
36\end{array}$ & $\begin{array}{l}.0867 \\
.2322 \\
.0000\end{array}$ & $\begin{array}{r}.4074 \\
2.1133 \\
.0351\end{array}$ & $\begin{array}{r}.18660 \\
8 \\
.79457 \\
5 \\
.01170 \\
6\end{array}$ & $\begin{array}{r}.062193 \\
5 \\
.483144 \\
8 \\
.010930 \\
9\end{array}$ \\
\hline
\end{tabular}

\section{Perputaran Piutang}

Berdasarkan hasil statistic deskriptif yang disajikan dalam table 4.5 dapat dikethui jumlah sampel (N) sebanyak 36 dan berdistribusi normal. Dasi 36 observasi ini dapat diketahui nilai terkecil (minimum) perputaran piutang PT. ABM Otommotif Batam sebesar 0.0867 dan nilai tertinggi (maximum) sebesar 0,4074 Dari nilai minimum dan maksimum dapat diketahui perusahaan yang memiliki nilai minimum 0.0867 adalah Oktober tahun 2014 dan nilai maksimum 0.4074 adalah Juni tahun 2014. Sedangkan nilai rata - rata (mean) sebesar 0,186608 dan nilai standard deviasi sebesar 0,0621935 .

\section{Perputaran Persediaan}

Berdasarkan hasil statistic deskriptif yang disajikan dalam table 4.5 dapat diketahui jumlah sampel (N) sebanyak 36 dan berdistribusi normal. Dari 36 observasi ini dapat diketahui nilai terkecil (minimum) 
perputaran persediaan PT. ABM Otomotif Batam sebesar 0,2322 dan nilai tertinggi (maximum) sebesar 2,1133. Dari nilai minimum dan maksimum dapat diketahui perusahaan yang memiliki nilai minimum 1.2322 adalah Agustus tahun 2014 dan nilai maksimum 2,1133 adalah November tahun 2016. Sedanglkan nilai rata - rata (mean) sebesar 0,794575 dan nilai standard deviasi sebesar 0,4831448 .

\section{Rentabilitas (Return On Asset)}

ROA adalah salah satu bentuk dari rasio profitabilitas?Rentabilitas untuk mengukur kemampuan perusahaan dalam menghasilkan laba dengan menggunakan total aktiva yang ada dan setelah biaya biaya modal (biaya yang digunakan mendanai aktva) dikeluarkan dari analisa.

Berdasarkan hasil statistic deskriptif yang disajikan dalam table. 4.5 dapat diketahui jumlah sanple (N) sebanyak 36 dan berdistribusi normal. Dari 36 observasi ini dapat diketahui nilai terkenil (minimum) return on asset perusahaan PT. ABM Otomotif Batam sebesar 0,00000 dan nilai tertinggi (maximum) sebesar 0,0351. Dari nilai minimum dan maksimum dapat diketahui perusahaan yang memiliki nilai minimum 0,00000 ada;ah Oktober tahun 2014 dan nilai maksimum 0,0351 adalah
Agustus 2014. Sedangkan nilai rata - rata (mean) sebesar 0,11706 dan nilai standard deviasi sebesar 0.0109309

\section{Hasil Uji Asumsi Klasik}

Salah satu syarat yang menjadi dasar penggunaan model regresi berganda adalah dipenuhi semua asumsi klasik. Pengujian asumsi klasik dalam penelitian ini dilakukan dengan bantuan program statistic. Asumsi klasik yang harus dipenuhi adalah:

1. Berdistribusi normal, artinya apakah dalam model regresi, variabel pengganggu atau residual memiliki distribusi normal.

2. Non-Multikolinearitas, artinya antara variabel independen dalam model regresi tidak memiliki korelasi atau hubungan secara sempurna ataupun mendekati sempurna.

3. Non-Autokorelasi, artinya kesalahan pengganggu dalam model regresi tidak saling berkorelasi.

4. Non-Heterokedastisitas, artinya variance variabel independen dari satu pengamatan ke pengamatan lain adalah konstan atau sama.

\section{Uji Normalisasi}

Uji normalitas merupakan sebuah uji yang dilakukan dengan tujuan untuk menilai sebaran data pada sebuah kelompok data atau variabel, apakah seberan 
data tersebut berdistribusi normal atau tidak. Uji normalitas dapat digunakan uji nonparametric kolmogorov-smirnov satu sampel (K-S). Uji nonparametric kolmogorov-smirnov satu sampel (K-S) dilakukan

untuk memperkuat uji normalitas yang secara visual kelihatan normal pada normal probability plots. Hasil pengujian nonparametrik kolmogorov-smirnov satu sampel (K-S) dapat dilihat pada tabel 4.3

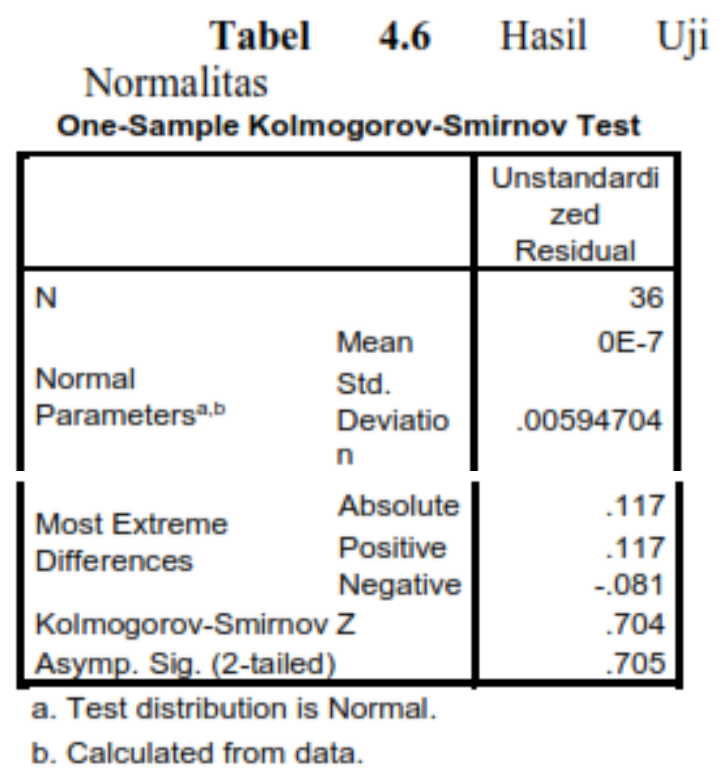

\section{Sumber: Hasil Olahan SPSS 20}

Hasil analisis metode one-sample Kolmogrov-Smirnov diatas dapat disimpulkan bahwa asumsi normalitas terpenuhi. Hal ini terlihat dari nilai Asymp. Sig. (2-tailed) dari tabel penelitian ini lebih besar dari 0,05 yaitu sebesar 0,705

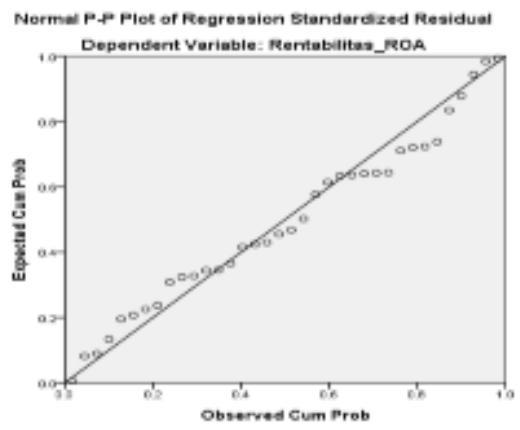

Gambar 4.2 Hasil Uji Normalitas dengan P-Plot

Sumber: Hasil Olahan SPSS 20

Berdasarkan hasil pengolahan SPSS yang ditunjukan oleh gambar 4.2 menunjukan bahwa data tersebut pada model regresi linear berdistribusi normal. Pada dasarnya normalitas sebuah data dapat dikenali atau dideteksi dengan melihat persebaran data (titik) pada sumbu diagonal dari grafik histogram dari residualnya, hal tersebut dapat dilihat dari data disekitar garis diagonal menyebar dan mengikuti arah garis diagonal.

\section{Uji Multikolinearitas}

Uji Multikolineritas bertujuan untuk menguji apakah model regresi ditemukan adanya korelasi antar variabel bebas (independen). Hasil pengujian multikolinieritas dengan nilai VIF dan nilai tolerance adalah sebagai berikut: 
Tabel 4.7 Hasil Uji Multikolinearitas Coefficients ${ }^{a}$

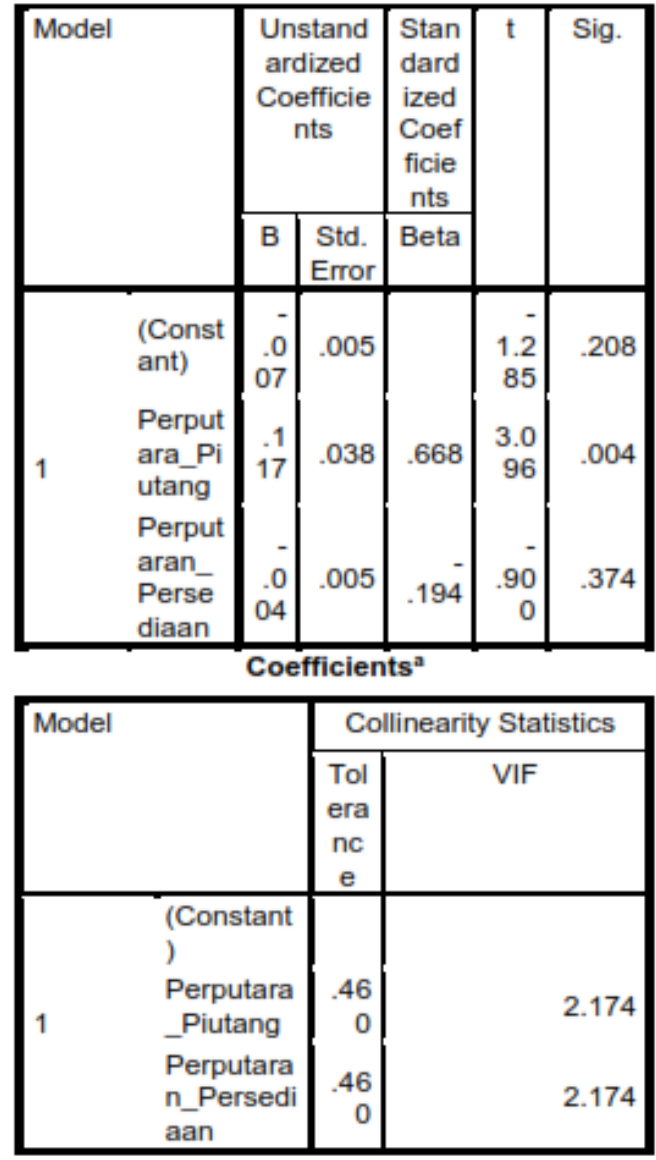

a. Dependent Variable: Rentabilitas_ROA Sumber: Hasil Olahan SPSS 20

Hasil pengujian menunjukan bahwa semua variabel yang digunakan sebagai prediktor model regresi menunjukan nilai VIF berada dibawah 10,00 dan nilai tolerance lebih dari 0,10 . Hal ini berarti bahwa variabel-variabel bebas yang digunakan dalam penelitian tidak menunjukan adanya gejala multikolinieritas.

\section{Uji Heteroskedastisitas}

Terjadinya heteroskedastisitas jika terdapat korelasi signifikan antara variabel-variabel independen dengan residualnya. Cara yang dilakukan untuk mendeteksi terjadinya Heterosdastisitas dalam suatu model regresi adalah dengan menggunakan metode Barlet dan Rank Spearman atau uji Spearman's rho dan metode grafik Park Gleyser. Jika hasil profitabilitasnya memiliki signifikan > nilai $\alpha(0,05)$ maka model tidak mengalami heteroskedastisitas.

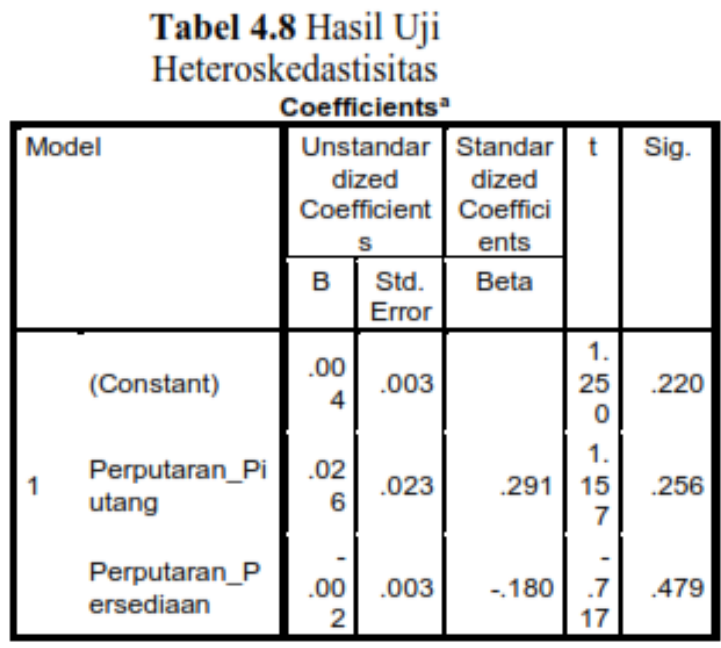

a. Dependent Variable: RES2

Sumber: Hasil Olahan SPSS 20

Berdasarkan output diatas diketahui bahwa nilai signifikan variabel perputaran piutang (X1) sebesar 0,256 lebih besar dari 0,05 , artinya tidak terjadi heteroskedastisitas pada variabel perputaran piutang (X1). Sementara itu, diketahui nilai signifikan variabel perputaran persediaan (X2) yakni 0,479 lebih besar dari 0,05 artinya tidak terjadi heteroskedastisitas juga pada perputaran persediaan (X2).

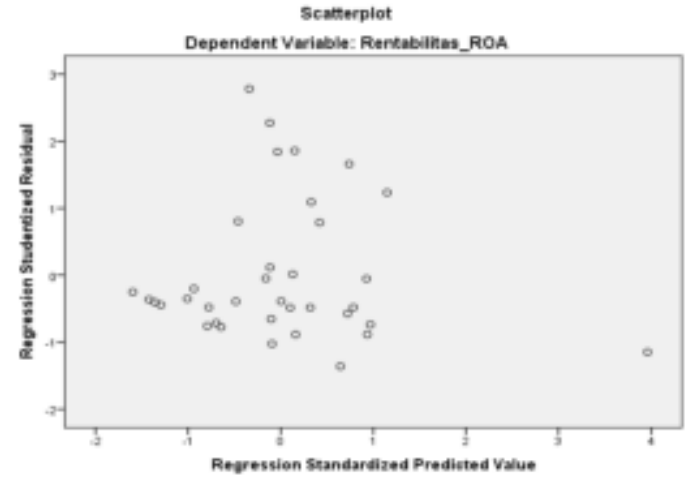


Gambar 4.3 Hasil Uji

Heteroskedastisitas Scatterplot

\section{Sumber : Hasil Olahan SPSS}

Berdasarkan hasil pengolahan SPSS yang ditunjukkan oleh gambar 4.3 menunjukkan bahwa titik - titik data menyebar diatas dan dibawah atau disekitar angka 0 , titik - titik tidak mengumpul hanya diatas atau dibawah saja, penyebaran titik - titik tidak membentuk pola bergelombang melebar kemudian menyempit dan melebar kembali dan penyebaran titik - titik data tidak berpola, dengan demikian dapat disimpulkan tidak terjadi heteroskedastisitas.

\section{Uji Autokorelasi}

Uji autokorelasi digunakan untuk mengetahui ada tidaknya korelasi antara kesalahan pengganggu pada periode tertentu dengan kesalahan pengganggu periode sebekumnya. Model regresi yang baik adalah regresi yang bebas dari autokorelasi. Uji autokorelasi dapat dilakukan dengan pengujian Durbin - Watson.

Tabel 4.9 Hasil Uji Autokorelasi

\begin{tabular}{|l|r|r|r|r|r|}
\hline Model & $R$ & $\begin{array}{c}R \\
\text { Squ } \\
\text { are }\end{array}$ & $\begin{array}{c}\text { Adjust } \\
\text { ed R } \\
\text { Square }\end{array}$ & $\begin{array}{c}\text { Std. } \\
\text { Error of } \\
\text { the } \\
\text { Estimate }\end{array}$ & $\begin{array}{r}\text { Durbin- } \\
\text { Watson }\end{array}$ \\
\hline 1 & $\begin{array}{rrr}542 \\
\mathrm{a}\end{array}$ & .293 & .250 & .0094635 & 1.570 \\
\hline
\end{tabular}

a. Predictors: (Constant), Perputaran_Persediaan, Perputara_Piutang

b. Dependent Variable: Rentabilitas_ROA

Sumber: Hasil Olahan SPSS 20
Dari Tabel 4.9 dapat dilihat bahwa nilai Durbin - Watson dalam penelitian ini sebesar 1,570. Secara sederhana dapat dikatakan bahwa suatu model dapat dinyatakan tidak terjadi gejala autokorelasi, jika probabilitas nilai Durnin - Watson > 0,05. Pada table diatas probabilitas diperoleh nilai Durbin - Watson adalah 1,570 > 0,05, maka dapat dipastikan pada penelitian ini tidak mengalami gejala aotukorelasi.

\section{Analisis Regresi Linear Berganda}

Beberapa tahapan untuk mencari hubungan antara variable dependen. Hasil persamaan regresi linear dalam penelitian ini dapat dilihat pada Table 4.10 berikut ini :

Tabel 4.10 Hasil Uji Persamaan

Regresi Linear Berganda

Coefficients ${ }^{a}$

\begin{tabular}{|c|c|c|c|c|c|c|}
\hline \multirow{2}{*}{\multicolumn{2}{|c|}{ Model }} & \multicolumn{2}{|c|}{$\begin{array}{c}\text { Unstandard } \\
\text { ized } \\
\text { Coefficients }\end{array}$} & \multirow{2}{*}{$\begin{array}{c}\begin{array}{c}\text { Standar } \\
\text { dized } \\
\text { Coeffici } \\
\text { ents }\end{array} \\
\text { Beta }\end{array}$} & \multirow[t]{2}{*}{$\mathrm{T}$} & \multirow[t]{2}{*}{ Sig. } \\
\hline & & B & $\begin{array}{l}\text { Std. } \\
\text { Error }\end{array}$ & & & \\
\hline \multirow{3}{*}{1} & (Constant) & .007 & .005 & & $\begin{array}{r}1.2 \\
85\end{array}$ & .208 \\
\hline & $\begin{array}{l}\text { Perputara_Piut } \\
\text { ang }\end{array}$ & .117 & .038 & .668 & $\begin{array}{r}3.0 \\
96\end{array}$ & .004 \\
\hline & $\begin{array}{l}\text { Perputaran_P } \\
\text { ersediaan }\end{array}$ & .004 & .005 & -194 & $\begin{array}{r}- \\
90 \\
0\end{array}$ & .374 \\
\hline
\end{tabular}

Dari output diatas menunjukkan bahwa nilai sig. untuk perputaran piutang adalah sebesar 0,004 ( $\mathrm{p}<0,05)$ maka dari itu hipotesis diterima, artinya varibel perputaran 
piutang berpengaruh signifikan terhadap rentabilitas perusahaan (Return On Asset). Selanjutnya untuk variable perputaran persediaan, data diatas menunjukkan nilai sig.sebesar 0,374 $(\mathrm{p}<0,05)$ maka dari hipotesis ditolak, yang artinya varibel perputaran persediaan tidak berpengaruh signifikan terhadap rentabilitas perusahaan ( $R e$ turn On Asset).

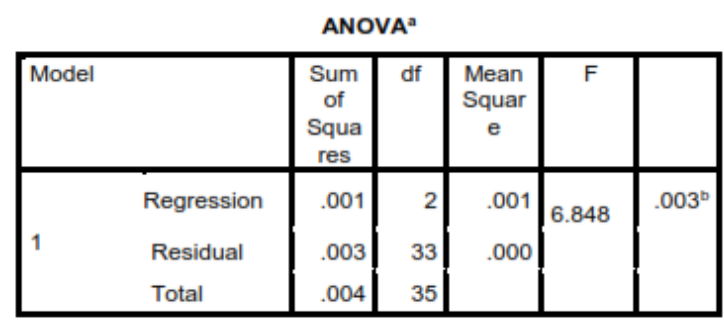

a. Dependent Variable: Rentabilitas_ROA

b. Predictors: (Constant), Perputaran_Persediaan, Perputara_Piutang

Berdasarkan data diatas, didapatkan nilai sig. $F$ sebesar $0,003(\mathrm{p}<0,05)$ maka dapat disimpulkan bahwa hipotesis diterima, artinya variabel perputaran piutang dan persediaan berpengaruh simultan terhadap rentabilitas perusahaan ( Return On Asset ).

\section{Uji Hipotesis}

\section{Uji Statistik t}

Uji statistik t dilakukan untuk menguji pengaruh variabel perputaran piutang dan perputaran persediaan secara parsial terhadap Rentabilitas (return on assets) d pada PT Otomotif Batam dengan asumsi bahwa variabel lain dianggap konstan atau sama dengan nol. Hasil uji statistik t dalam penelitian ini dapat dilihat pada Tabel 4.11 berikut

ini:

Tabel 4.11 Hasil Uji Statistik t

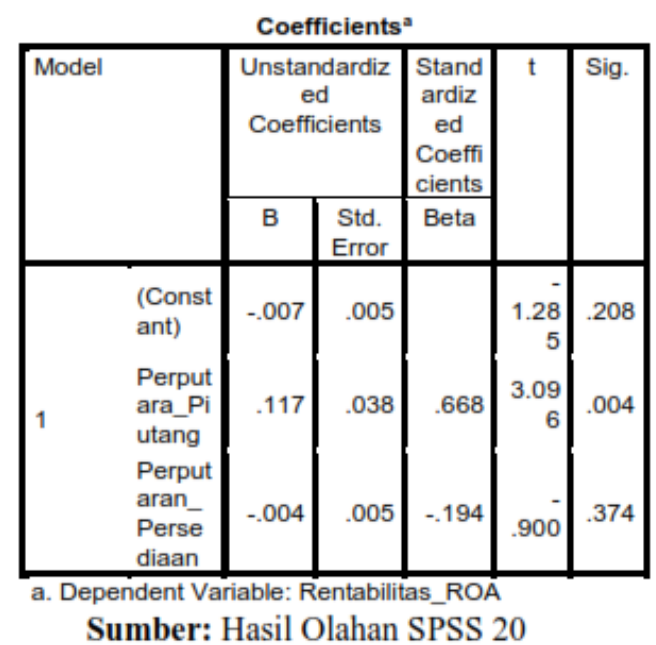

Berdasarkan hasil uji $t$ yang disajikan pada tabel 4.11 dapat diketahui bahwa perputaran piutang (PerPiutang) memiliki nilai thitung sebesar 3,096 dan tabel sebesar 2,0345 ( $\alpha$ sebesar 0,050 dan degree of freedom sebesar $\mathrm{n}-\mathrm{k}=36-3=33$ ) dengan nilai $\mathrm{t}$ signifikan sebesar 0,004 maka nilai thitung $>$ ttabel. Nilai t signifikan ini lebih kecil dari tingkat signifikansi yakni sebesar 0,05 sehingga $\mathrm{H}_{01}$ ditolak dan $\mathrm{H}_{\mathrm{a}}$ diterima, yang berarti variabel perputaran piutang (PerPiutang) secara parsial berpengaruh signifikan dan positif terhadap Rentabilitas (return on assets). Perputaran persediaan memiliki nilai thitung sebesar $-0,900$ dan tabel sebesar 2,0345 ( $\alpha$ sebesar 0,050 dan degree of freedom sebesar $n-k=36-3=33$ ) dengan nilai $t$ signifikan sebesar 0,374 maka nilai thitung < tabel. Nilai $t$ signifikan ini lebih besar dari nilai signifikansi yakni sebesar 0,05 sehingga $\mathrm{H}_{2}$ diterima dan $\mathrm{H}_{\mathrm{a} 2}$ ditolak, yang berarti variabel perputaran persediaan secara parsial tidak berpengaruh signifikan terhadap Rentabilitas (return on assets). 


\section{Uji Statistik F}

Uji statistik F digunakan untuk

mengetahui apakah variabel independen yang digunakan dalam model mempunyai pengaruh secara simultan terhadap variabel dependen. Hasil Uji statistik F dalam penelitian ini dapat dilihat pada Tabel 4.12 berikut ini:

Berdasarkan hasil uji statistic $\mathrm{F}$ pada Tabel 4.12 menunjukkan bahwa nilai $F$ signifikan sebesar 0,003 $<0,05$ dan Fhitung $>$ Ftabel, di mana Fhitung 6,848 dan F tabel bila dilihat dari tabel statistik dengan $\alpha 0,05$ adalah sebesar 3,28. Dengan demikian dapat disimpulkan bahwa nilai Fhitung $>$ Ftable atau 6,848 > 3,28, maka $\mathrm{H}_{03}$ ditolak dan $\mathrm{H}_{3} 3$ diterima. Hal ini menunjukkan bahwa variabel perputaran piutang dan perputaran persediaan secara simultan berpengaruh terhadap Rentabilitas (return on assets).

\section{Koefisien determinasi $\left(\mathbf{R}^{2}\right)$}

Hasil uji hipotesis yang menyatakan bahwa likuiditas dan profitabilitas mempunyai pengaruh terhadap struktur modal, untuk meyakinkan atau tingkat kekuatan hubungan antar variabel dapat dilihat pada Tabel 4.13 koefisien determinasi berikut ini:
Tabel 4.12 Hasil Uji Statistik F

ANOVA $^{a}$

\begin{tabular}{|l|r|r|r|r|r|}
\hline Model & $\begin{array}{c}\text { Sum of } \\
\text { Squares }\end{array}$ & df & $\begin{array}{c}\text { Mean } \\
\text { Square }\end{array}$ & $\mathrm{F}$ & Sig. \\
\hline $\begin{array}{l}\text { Regress } \\
\text { ion } \\
\begin{array}{l}\text { Residua } \\
\text { I }\end{array}\end{array}$ & .001 & 2 & .001 & 6.848 & $.003^{\mathrm{b}}$ \\
& .003 & 33 & .000 & & \\
Total & .004 & 35 & & & \\
a. Dependent Variable: Rentabilitas_ROA & &
\end{tabular}

Tabel 4.13 Hasil Uji Koefisien Determinasi $\left(\mathrm{R}^{2}\right)$ Model Summary ${ }^{\mathrm{b}}$

\begin{tabular}{|c|c|c|c|c|c|}
\hline $\begin{array}{l}\text { M } \\
\text { od } \\
\text { el }\end{array}$ & $\mathrm{R}$ & $\begin{array}{c}\mathrm{R} \\
\text { Squ } \\
\text { are }\end{array}$ & $\begin{array}{c}\text { Adjuste } \\
\text { d R } \\
\text { Square }\end{array}$ & $\begin{array}{c}\text { Std. } \\
\text { Error of } \\
\text { the } \\
\text { Estimat } \\
\mathrm{e}\end{array}$ & $\begin{array}{l}\text { Durbin- } \\
\text { Watson }\end{array}$ \\
\hline 1 & $\begin{array}{r}.542 \\
\mathrm{a}\end{array}$ & .293 & .250 & \begin{tabular}{|r|}
.00946 \\
35
\end{tabular} & 1.570 \\
\hline
\end{tabular}

Sumber : hasil olahan SPSS 20

Dari Tabel 4.13 dapat dilihat bahwa nilai Adjusted $R$ Square sebesar 0,293 atau $29,3 \%$ artinya variabel independen yaitu perputaran piutang dan perputaran persediaan dapat menjelaskan variabel dependen yaitu Rentabilitas (return on assets) sebesar $29,3 \%$ sedangkan sisanya sebesar 70,7\% dijelaskan oleh variabel lain yang tidak dimasukkan dalam model penelitian.

\section{PEMBAHASAN}

Penelitian ini bertujuan untuk menguji apakah ada pengaruh antara variabel independen, yaitu perputaran piutang $\left(\mathrm{X}_{1}\right)$ 
perputaran persediaan $\left(\mathrm{X}_{2}\right)$ terhadap variabel dependen yaitu Rentabilitas yang mana rasio yang digunakan peneliti adala Rentabilitas (Return On Asset/Y). Setelah melakukan analisa deskriptif dan serangkaian uji asumsi klasik maupun uji hipotesis dari data yang diperoleh, maka pada bab pembahasan akan dijelaskan ringkasan penjelasan yang dirangkum dari hasil penelitian mengenai perputaran piutang dan perputaran persediaan terhadap rentabilitas (Return On Asset).

\section{Pengaruh Perputaran Piutang (PerPi- utang) Terhadap Rentabilitas (ROA)}

Hipotesis pertama yang diajukan pada penelitian ini adalah terdapat pengaruh perputaran piutang (PerPiutang) terhadap Rentabilitas (return on assets). Berdasarkan perhitungan regresi diperoleh nilai thitung sebesar 3,096 dan tabel sebesar 2,034 dengan hasil signifikansi yang diperoleh adalah 0,004 dimana nilai signifikan ini lebih kecil dari tingkat signifikansi yakni sebesar 0,05, maka dapat disimpulkan bahwa perputaran piutang (PerPiutang) berpengaruh signifikan dan positif terhadap return on assets sehingga Hipotesis pertama dapat diterima. Hasil ini sejalan dengan penelitian Winanto Nawarcono (ISSN-1411-3880) dimana adanya pengaruh yang signifikan antara perputaran piutang terhadap rentabilitas.

\section{Pengaruh Perputaran Persediaan (Per- Persediaan) Terhadap Rentabilitas (ROA)}

Hipotesis kedua yang diajukan pada penelitian ini adalah terdapat pengaruh perputaran persediaan terhadap return on assets. Berdasarkan perhitungan regresi diperoleh nilai thitung sebesar $-0,900$ dan tabel sebesar 2,034 dengan hasil signifikansi yang diperoleh adalah 0,374. Jika dilihat dari hasil besarnya signifikansi yang lebih besar dari
0,05 maka dapat disimpulkan bahwa perputaran persediaan tidak berpengaruh signifikan terhadap Rentabilitas (return on assets). Maka Hipotesis kedua ditolak. Hasil ini sejalan dengan Elis Rosmiati (2009) dimana tidak terdapat pengaruh yang signifikan anatar perputaran persediaan terhadap Profitabilitas/Rentabilitas.

\section{Pengaruh Perputaran Piutang dan Per- putaran Persediaan terhadap Rentabilitas} (ROA)

Hopotesi yang ketiga yang diajukan pada penelitian ini adalah perputaran piutang dan perputaran persediaan secara simultan berpengaruh terhadap return on assets. Berdasarkan perhitungan regresi diperoleh $\mathrm{F}$ hitung sebesar 6,848 dengan hasil signifikansi yang diperoleh adalah 0,003 . Jika dilihat dari hasil besarnya signifikansi yang lebih kecil dari 0,05 maka dapat disimpulkan bahwa perputaran piutang dan perputaran persediaan berpengaruh simultan terhadap return on assets sehingga hipotesis ketiga diterima. Hasil ini sejalan dengan Hj. Arna Suryani (2016) dimana berdasarkan uji simultan diketahui bahwa tingkat perputaran piutang dan persediaan berpengaruh secara simultan terhadap Rentabilitas.

\section{KESIMPULAN DAN SARAN}

\section{Kesimpulan}

Berdasarkan hasil penelitian dan pembahasan yang diuraikan di atas, maka penulis menarik kesimpulan adalah sebagai berikut:

1. Perputaran piutang $\left(\mathrm{X}_{1}\right)$ secara parsial memiliki pengaruh signifikan terhadap Rentabilitas (return on assets), hal tersebut dapat dilihat dimana variable perputaran piutang 
(X1) mempunyai nilai thitung sebesar 3,096 lebih besar daripada tabel 2,034 dan nilai signifikansi t sebesar 0,004. Maka hipotesis Ho1 ditolak dan $\mathrm{H}_{\mathrm{a} 1}$ diterima yang artinya adalah terdapat pengaruh yang signifikan antara perputaran piutang terhadap rentabilitas (Return On Asset) pada PT. ABM Otomotif Batam tahun 2014-2016.

2. Perputaran persediaan $\left(\mathrm{X}_{2}\right)$ secara parsial tidak memiliki pengaruh signifikan terhadap return on assets, hal tersebut dapat dilihat dimana variabel perputaran persediaan $\left(\mathrm{X}_{2}\right)$ mempunyai nilai thitung sebesar $(0,900)$ lebih kecil dari tabel 2,034 dan nilai signifikansi $\mathrm{t}$ sebesar 0,374. Maka hipotesis Ho1 diterima dan $\mathrm{H}_{\mathrm{a} 1}$ ditolak yang artinya adalah tidak terdapat pengaruh yang signifikan antara perputaran persediaan terhadap rentabilitas (Return On Asset) pada PT. ABM Otomotif Batam tahun 2014-2016.

3. Perputaran piutang ( $\left.\mathrm{X}_{1}\right)$ dan perputaran persediaan $\left(\mathrm{X}_{2}\right)$ secara simultan berpengaruh signifikan terhadap return on assets, dimana variabel perputaran piutang $\left(\mathrm{X}_{1}\right)$ dan perputaran persediaan $\left(\mathrm{X}_{2}\right)$ mempunyai nilai Fhitung sebesar 6,848 dan nilai signifikansi $\mathrm{F}$ sebesar 0,003. Maka hipotesis $\mathrm{H}_{\mathrm{a}}$ diterima dan $\mathrm{Ho}$ ditolak yang artinya adalah terdapat pengaruh secara simultan antara perputaran piutang dan perputaran persediaan terhadap rentabilitas (Return On Asset) pada PT. ABM Otomotif Batam tahun 2014-2016.

\section{Saran}

Adapun saran-saran yang ingin peneliti sampaikan untuk:
1. Bagi perusahaan supaya lebih fokus dalam memahami return on assets karena return on assets bisa menganalisa efesiensi penggunaan modal yang bekerja, efisiensi produksi dan efisiensi bagian penjualan dan menjadi masukan positif bagi perusahaan didalammenentukan kebijakan perusahaan dimasa yang akan dating khususnya menyangkut perputaran piutang, perputaran persediaan dan rentabilitas.

2. Bagi Universitas diharapkan agar hasil penelitian ini dapat memberikan manfaat bagi universitas dibidang akuntansi khususnya mengenai piutang, persediaan dan rentabilitas.

3. Bagi peneliti selanjutnya disarankan untuk menambah populasi dalam penelitian dan mengambil atau menambahkan variabel-variabel lain, supaya lebih menambah wawasan bagi peneliti selanjutnya, karena rentabilitas tidak hanya dipengaruh oleh piutang dan persediaan akan tetapi juga dipengaruhi yang lainnya, misal perputaran kas.

\section{DAFTAR PUSTAKA}

Ghozali, I. 2011. Aplikasi Analisis Multivariate Dengan Program SPSS. Semarang:Cetakan kelima.Badan Penerbit Universitas Diponegoro.

Hery. 2015. Praktis Menyusun Laporan Keuangan. Jakarta: PT. Gramedia Widiasarana Indonesia

Kasmir. 2008 . Analisis Laporan Keuangan. Jakarta: Penerbit Rajawali Pers

Kasmir. 2010. Pengantar Manajemen Keuangan. Jakarta: 
Kencana Preneda Media Group.

Munawir, S 2010. Analisis Laporan Keuangan. Yogyakarta: Liberty

Murtiningsih, Tri. 2016. Pengaruh Tingkat Perputaran Kas, Tingkat Perputaran Piutang, Tingkat Perputaran Persediaan terhadap Rentabilitas.

(Skripsi). Kediri: Universitas Nusantara PGRI

Nawarcono, Winanto.Pengaruh Tingkat Perputaran Piutang, Persediaan dan Modal Kerja terhadap Rentabilitas Ekonomi (Studi Kasus Perusahaan Manufactur yang Terdaftar di BEI Tahun 2007 - 2009). ISSN -14113880.

N. Rahma, 2011. Pengaruh Perputaran Piutang dan Perputaran Kas terhadap Laba Usaha pada Perusahaan Barang Konsumsi Terdaftar di Bursa Efek Indonesia (BEI). Jurnal Penelitian. Vol.3(1): 31-49.

Putri Ayu Diana dan Bambang Hadi Santoso. 2016. Pengaruh Perputaran Kas, Piutang, Persediaan terhadap Profitabilitas pada Perusahaan Semen di BEI. Jurnal Ilmu dan Riset Manajemen: Volume 5, Nomor 3, Maret 2016.

Riyanto, Bambang. 2010, Dasar-dasar Pembelajaran Perusahaan Edisi Keempat. Yogyakarta: BPFE

Rosmiati, Elis. 2009. Pengaruh Perputaran Piutang dan Perputaran Persediaan terhadap Profitabilitas pada Perusahaan pada Barang Konsumsi yang Terdaftar di BEI 2005 - 200).
Bandung: Universitas Widyatama

Suryani, Hj, Anna. 2016. Analisa Pengaruh Tingkat Perputaran Piutang dan Tingkat Perputaran Persediaan terhadap Rentabilitas Ekonomi PT. Afresh Indonesia Jambi. (Jurnal Ilmiah). Jambi: Universitas Batanghari Vol. 16 No.1 Tahun 2016.

Sofyan Syafri, Harahap. 2010. Analisa Kritis atas Laporan Keuangan. Jakarta: Rajawali Pers

Subramanyam. 2010. Analisa Laporan Keungan Buku 1. Jakarta : Salemba Empat 